\title{
RND-type drug efflux pumps from Gram-negative bacteria: molecular mechanism and inhibition
}

\author{
Henrietta Venter ${ }^{1 *}$, Rumana Mowla ${ }^{1}$, Thelma Ohene-Agyei ${ }^{2}$ and Shutao $\mathrm{Ma}^{3}$ \\ 'School of Pharmacy and Medical Sciences, Sansom Institute for Health Research, University of South Australia, Adelaide, \\ SA, Australia, ${ }^{2}$ Department of Pharmacology, University of Cambridge, Cambridge, UK, ${ }^{3}$ Department of Medicinal \\ Chemistry, School of Pharmaceutical Sciences, Shandong University, Jinan, China
}

OPEN ACCESS

Edited by:

Attilio Vittorio Vargiu,

Universita' di Cagliari, Italy

Reviewed by:

Pierre Cornelis,

Vrije Universiteit Brussel, Belgium

Paolo Ruggerone,

University of Cagliari, Italy

*Correspondence:

Henrietta Venter

School of Pharmacy and Medical Sciences, Sansom Institute for Health

Research, University of South Australia, Frome Road, Adelaide,

SA 5000, Australia

rietie.venter@unisa.edu.au

Specialty section:

This article was submitted to Antimicrobials, Resistance and Chemotherapy,

a section of the journa

Frontiers in Microbiology

Received: 26 January 2015

Paper pending published:

02 March 2015

Accepted: 12 April 2015

Published: 28 April 2015

Citation:

Venter H, Mowla R, Ohene-Agyei T and Ma S (2015) RND-type drug efflux pumps from Gram-negative bacteria: molecular mechanism and inhibition.

Front. Microbiol. 6:377.

doi: 10.3389/fmicb.2015.00377
Drug efflux protein complexes confer multidrug resistance on bacteria by transporting a wide spectrum of structurally diverse antibiotics. Moreover, organisms can only acquire resistance in the presence of an active efflux pump. The substrate range of drug efflux pumps is not limited to antibiotics, but it also includes toxins, dyes, detergents, lipids, and molecules involved in quorum sensing; hence efflux pumps are also associated with virulence and biofilm formation. Inhibitors of efflux pumps are therefore attractive compounds to reverse multidrug resistance and to prevent the development of resistance in clinically relevant bacterial pathogens. Recent successes on the structure determination and functional analysis of the AcrB and MexB components of the AcrAB-TolC and MexAB-OprM drug efflux systems as well as the structure of the fully assembled, functional triparted AcrAB-TolC complex significantly contributed to our understanding of the mechanism of substrate transport and the options for inhibition of efflux. These data, combined with the well-developed methodologies for measuring efflux pump inhibition, could allow the rational design, and subsequent experimental verification of potential efflux pump inhibitors (EPIs). In this review we will explore how the available biochemical and structural information can be translated into the discovery and development of new compounds that could reverse drug resistance in Gram-negative pathogens. The current literature on EPIs will also be analyzed and the reasons why no compounds have yet progressed into clinical use will be explored.

Keywords: multidrug resistance, drug efflux, efflux pump inhibitor, Gram-negative, pathogen, antimicrobial resistance

\section{Introduction}

Over the last two decades there has been a dramatic surge in the number of multidrug resistant bacteria, yet paradoxically the number of pharmaceutical companies developing new antimicrobial agents has dwindled during this same period. As a result, antibiotic resistance is now one of the world's most pressing health problems (WHO, 2014). Therefore, new treatments to combat drug resistant bacteria are urgently needed if we do not want to return to the high mortality rates associated with infections during the pre-antibiotic era (Bush et al., 2011; WHO, 2014).

Hospital acquired pathogens such as Staphylococcus aureus, Klebsiella pneumonia, Acinetobacter baumannii, and Pseudomonas aeruginosa which can cause life-threatening infections display high levels of antibiotic resistance (Poole, 2011; Bassetti et al., 2013). Resistance of K. pneumonia 
to carbapenems, the last resort treatment for severe infections, of up to $54 \%$ of cases were reported (WHO, 2014).

Recently a few new antibiotics have been approved for the use against Gram-positive organisms (Butler and Cooper, 2011). However, infections caused by Gram-negative pathogens proved much harder to treat due to the very high intrinsic drug resistance displayed by Gram-negative organisms. This intrinsic drug resistance is due to presence of an outer membrane which acts as a permeability barrier and by the expression of drug efflux pumps.

Drug efflux pumps are protein complexes which reside in the membrane and remove antimicrobials and toxins, thereby lowering their concentration inside the cell to sub-toxic levels (Poole, 2004, 2005; Piddock, 2006a; Nikaido and Pages, 2012). These proteins recognize and expel a wide range of structurally diverse antibiotics with different mechanisms and sites of action. The clinical implication of this substrate promiscuity is the development of multidrug resistance where a pathogen displays resistance against multiple classes of antimicrobials.

Apart from antibiotics drug efflux proteins can also transport antiseptics and disinfectants (Chuanchuen et al., 2003; Sanchez et al., 2005; Mima et al., 2007; Pumbwe et al., 2007), detergents (including naturally occurring bile salts; Rosenberg et al., 2003; Lin et al., 2005), fatty acids (Lee and Shafer, 1999; Lennen et al., 2013), heavy metals (Silver and Phung, 1996; Walmsley and Rosen, 2009), solvents (White et al., 1997; Ramos et al., 2002; Segura et al., 2012), and virulence factors (Piddock, 2006b). Therefore, drug efflux pumps are also important constituents of bacterial pathogenesis, virulence, and biofilm formation (Hirakata et al., 2002, 2009; Piddock, 2006b; Ikonomidis et al., 2008; Martinez et al., 2009; Baugh et al., 2012, 2014; Amaral et al., 2014). In addition, micro-organisms can only acquire resistance in the presence of drug efflux pumps (Lomovskaya and Bostian, 2006; Ricci et al., 2006; Zhang et al., 2011; Piddock, 2014) as these non-specific pumps remove most compounds until the organism has had time to acquire resistance to an antibiotic through more specific adaptive mechanisms.

Despite their crucial role in bacterial pathogenesis and multidrug resistance there are currently no inhibitors for drug efflux pumps in clinical use. Therefore drug efflux pumps are attractive targets for inhibition. Efflux pump inhibitors (EPIs) will (a) synergise with currently used antibiotics, (b) restore the efficacy of antibiotics to which resistance has arisen, (c) reduce the incidence of emergence of drug-resistant pathogens, (d) reduce the ability of pathogens to infect the host as the inhibition of efflux attenuates the bacterium, and (e) prevent the development of highly drug resistant biofilms

\section{Drug Efflux Pumps in Gram-Negative Bacteria}

Gram-negative pathogens rely on tripartite protein assemblies that span their double membrane to pump antibiotics from the cell. The tripartite complex consists of an inner membrane protein (IMP) of the resistance nodulation cell division (RND) family, an outer-membrane protein (OMP), and a periplasmic membrane fusion protein (MFP) which connect the other two proteins (Figure 1). The inner-membrane protein catalyses drug $/ \mathrm{H}^{+}$antiport and is the part of the complex responsible for drug selectivity. The best studied tripartite drug efflux complexes are the AcrA-AcrB-TolC and MexA-MexB-OprM transporters from Escherichia coli and $P$. aeruginosa, respectively, (Du et al., 2013). The IMPs AcrB and MexB share $86 \%$ similarity and $\mathrm{MexB}$ can functionally substitute for AcrB (Krishnamoorthy et al., 2008; Welch et al., 2010). The asymmetric structure of the AcrB homotrimer and subsequent biochemical analysis revealed a functional rotating mechanism where the monomers cycle through the different states loose (L), tight (T), and open (O; Murakami et al., 2006; Seeger et al., 2006, 2008b). IMPs such as AcrB consist of a transmembrane domain and periplasmic domain. The drug efflux pathway from the periplasm/outer membrane leaflet through the periplasmic domain of AcrB has been the focus of many studies and are now relatively well-understood (Murakami, 2008; Seeger et al., 2008a; Eicher et al., 2009; Misra and Bavro, 2009; Nikaido and Takatsuka, 2009; Pos, 2009; Nikaido, 2011; Nikaido and Pages, 2012; Ruggerone et al., 2013a,b). Recently, it was also found that mutations at the cytoplasmic face of MexB affected transport of drugs with targets inside the cell (Ohene-Agyei et al., 2012). This raises the possibility that similar to the cytoplasmic pathway for $\mathrm{Cu}$ (II) in CusA (Delmar et al., 2014), MexB might also have the ability to remove antibiotics from the inner membrane leaflet/cytoplasm (OheneAgyei et al., 2012). Targeted geometric simulations showed that such a cytoplasmic pathway could be possible even though it would not necessarily out-compete the periplasmic channel for

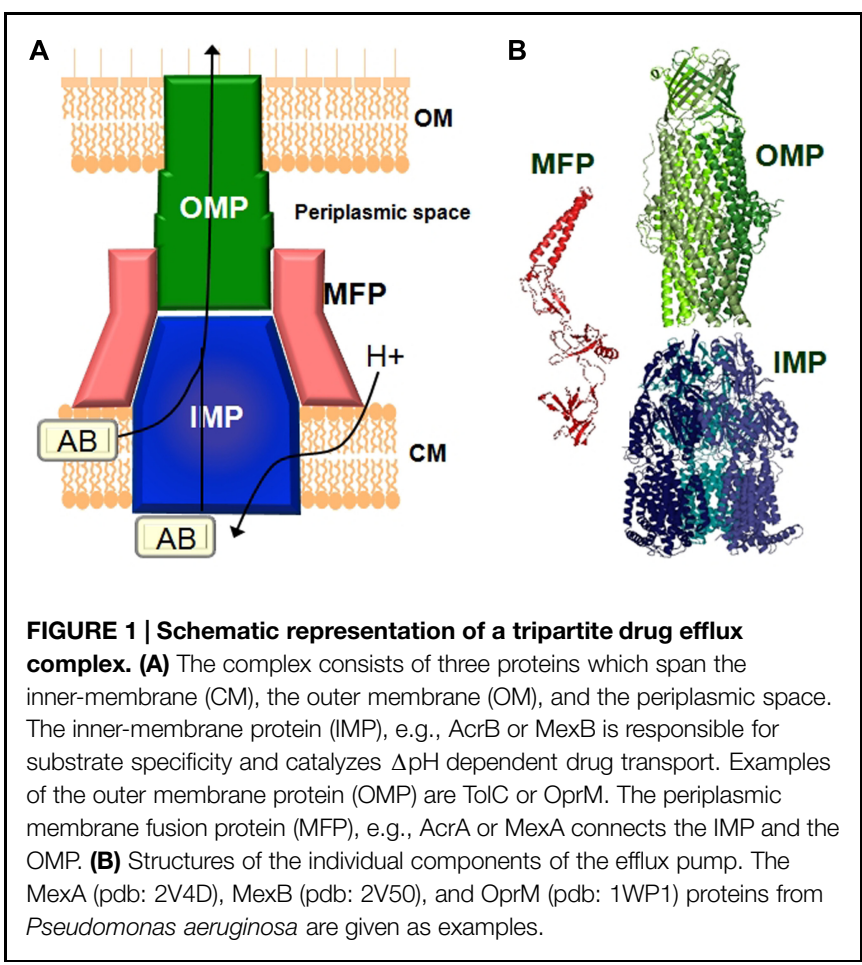


drug binding and transport (Phillips and Gnanakaran, 2015). Biochemical and structural analysis revealed that the perplasmic binding site in AcrB contains a shallow (proximal) and deep (distal) binding pocket separated by a switch loop (Gloop) consisting of residues 614-621 (Nakashima et al., 2011; Eicher et al., 2012; Cha et al., 2014). Conformational flexibility in this loop is necessary to move the substrate along the extended binding site. Mutations that change the small glycine residues in this loop to bulkier residues affects transport of larger macrolide antibiotics such as erythromycin while the activity toward smaller compounds such as novobiocin, ethidium, and chloramphenicol remained unaffected (Bohnert et al., 2008; Wehmeier et al., 2009; Nakashima et al., 2011, 2013; Eicher et al., 2012). Therefore, EPIs would most effectively inhibit the efflux of different antibiotics by interaction with the switch loop.

Due to the complexity of these macromolecular structures progress on elucidating their assembly and structure was slow. Only very recently Du et al. (2014) used a creative approach of genetic fusion proteins to solve the first structure of a partially active, fully assembled, tripartite pump in the presence of a modulatory partner. This structure of AcrA-AcrB-AcrZ-TolC shed light on long disputed subunit stoichiometries and revealed that the complex assembles in a $3: 6: 3$ ratio of AcrB : AcrA : TolC with one monomer of AcrZ bound to each subunit of AcrB. The role of the small protein AcrZ is not clear, however, as it alters the substrate specificity of AcrB (Hobbs et al., 2012) it most likely plays a modulatory role.

The structural similarity between transporters from different Gram-negative organisms means that EPIs developed against, e.g., the AcrA-AcrB-TolC efflux pump from E. coli would most likely be effective against other pathogens also. Our current understanding of the structure and function of RND efflux pumps from Gram-negative bacteria could therefore provide the basis for the informed and efficient design of inhibitors against these protein complexes.

\section{Approaches to Inhibit Drug Efflux}

The expression, function and assembly of drug efflux pumps of the RND class can be targeted in several ways (Figure 2).

\section{Targeting the Regulatory Network that Controls the Expression of Efflux Pumps as Levels of Pump Expression are Controlled by Activators and Repressors}

Some progress has already been made in understanding the regulation of efflux pump expression, e.g., expression of AcrB from Salmonella enterica (Blair et al., 2014) and the regulation of efflux pump expression in P. aeruginosa (Wilke et al., 2008; Starr et al., 2012; Hay et al., 2013; Purssell and Poole, 2013; Lau et al., 2014). The expression levels of efflux pumps could be measured by real time PCR or with green fluorescent protein reporter fusions (Bumann and Valdivia, 2007; Ricci et al., 2012). Both these methods are amenable to high-throughput processing.

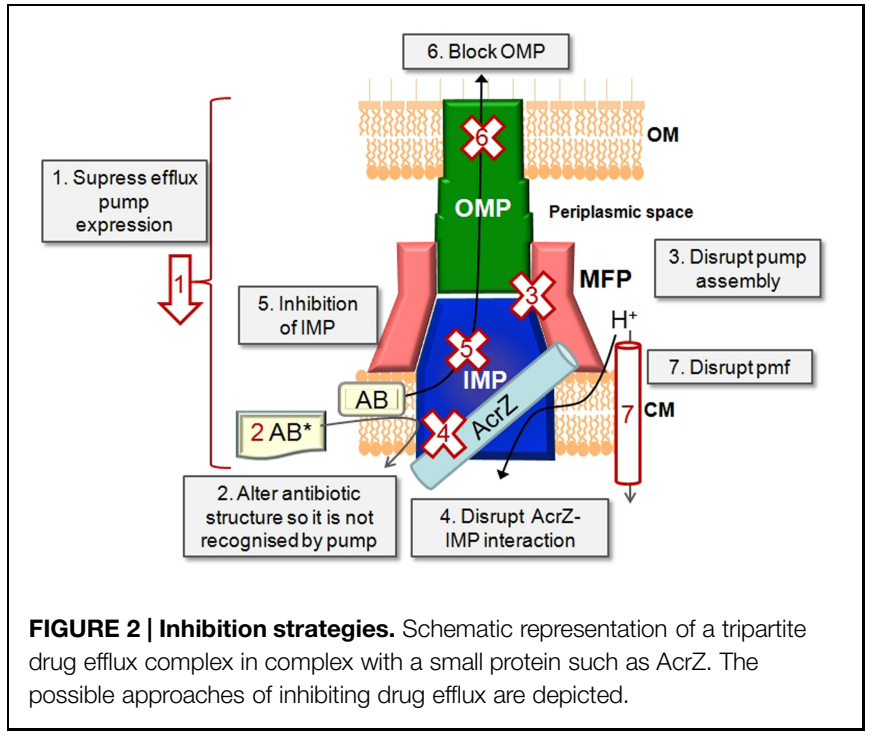

\section{Changing the Molecular Design of Old Antibiotics so that they are No Longer Recognized and Transported by the Efflux Pump}

Given the wide range of compounds which could be recognized by drug efflux transporters, the plasticity in the binding sites, and the redundancy in aromatic residues in the binding pocket which could stabilize substrate binding ( $\mathrm{Du}$ et al., 2013), this approach might prove a daunting task. In addition, altering the chemical structure of the antibiotic might render it less efficient against its intended cellular target. However, some progress has been made in this regard for a different class of drug efflux protein, the ATP binding cassette transporter, human P-glycoprotein where the substrate taxol was chemically modified so that P-glycoprotein no longer recognized it. This allowed the drug to cross the blood brain barrier and access its target receptor without being removed by P-glycoprotein (Rice et al., 2005).

\section{Preventing the Assembly of the Efflux Pump Components into a Functional Tripartite Pump by Targeting Protein-Protein Interfaces}

This is a very promising approach which is still under-developed due to the lack of information of how tripartite pumps assemble. However, Tikhonova et al. (2011) showed that designed ankyrin repeat proteins (DARPins) could inhibit AcrAB-TolC function by inhibiting the interaction between AcrA and AcrB. The recent structure of a complete tripartite drug efflux pump and the information gained from that also opens up exciting new possibilities (Du et al., 2014). The interaction of purified protein components of the pump with each other can be measured with surface plasmon resonance (SPR). The ability of efflux pumps to assemble in vivo can be measured by cross-linking in whole cells with subsequent co-purifying of the pump components (Welch et al., 2010). 


\section{Disrupting the Interaction Between AcrB and $A c r Z$}

The exact role of AcrZ in drug efflux is still ill-defined. However, as AcrA-AcrB-TolC has a diminished ability to confer resistance to some drugs in the absence of AcrZ (Hobbs et al., 2012), this approach could be promising for restoring sensitivity to some antibiotics. Homologs of AcrZ are found in most Gramnegative bacteria, therefore the modulatory effect of RND class of transporters by small proteins is probably a widely conserved occurrence. The interaction between the IMP and a small protein such as AcrZ could be measured with SPR or with cross-linking in cells as mentioned above.

\section{Directly Blocking the IMP with a High Affinity Competing Substrate or Trapping the IMP in an Inactive Conformation}

The recent crystal structure of $A c r B$ and $M e x B$ bound to an inhibitor (Nakashima et al., 2013) and the advances in our understanding of how drugs are bound makes this option very attractive (see Efflux Pump Inhibitors Against Gram-Negative Bacteria Identified So Far). The ability of compounds to inhibit antibiotic efflux can be measured using drug accumulation or drug efflux assays (see Inhibition of Substrate Transport), while direct interaction between the test compound and the IMP component could be determined with isothermal calorimetry (ITC) or SPR (Tikhonova et al., 2011).

\section{Blocking the Exit Duct (the OMP)}

A set of indole derivatives was designed based on the structure of TolC. These compounds were able to synergise with antibiotics and were reported to act on TolC specifically, presuming by preventing opening of the channel (Zeng et al., 2010). In addition, TolC from E. coli contains an electronegative entrance formed by an aspartate ring which is widely conserved throughout the TolC family and which could be a target for blocking by large cations (Andersen et al., 2002). The biggest challenge with this approach is achieving selectivity to the bacterial pores. Blocking of the OMP could be detected by inhibition of antibiotic efflux through the tripartite pump or by disruption of TolC-mediated conductance.

\section{Depleting the IMP From the Energy Needed to Drive the Drug/ $\mathbf{H}^{+}$Antiport Reaction}

The proton motive force (pmf) can easily be disrupted by the use of ionophores or compounds that disrupt the membrane integrity in one way or another. However, these effects are mostly not specific for bacterial membranes and hence compounds that act in this way would be cytotoxic to the host cells too. The magnitude of the pmf and the effect of test compounds on these could be determined by the use of fluorescent probes specific for the $\Delta \Psi$ or $\Delta \mathrm{pH}$ components of the pmf (Venter et al., 2003).

\section{How Could EPIs be Identified?}

Significant effort went into the biochemical and structural characterization of drug efflux proteins from Gram-negative bacteria.
Recent successes such as the structural determination of an intact pump and of IMPs bound to an inhibitor (Nakashima et al., 2013; Du et al., 2014) offer a solid platform for the rational design of EPIs using quantitative structure-activity relationship data (Ruggerone et al., 2013a; Wong et al., 2014; Figure 3).

Recently we used in silico screening to identify compounds which would bind to AcrB with reasonable affinity. Of the roughly fifty compounds docked, six compounds were selected for further study. The docking allowed us to provide an order of efficiency of the compounds as potential EPIs. The biochemical data compared well with the predictions from the docking showing that in silico screening could be used as an effective screening tool to limit the amount of experiments needed or save on precious and hard earned purified natural products (Ohene-Agyei et al., 2014).

Another approach with good scope for success is investigating compounds purified from plants (Tegos et al., 2002). Traditional peoples have used plants to treat infections for $100 \mathrm{~s}$ if not 1000 s of years. In western medicine, plants are thus far an under-utilized source of chemical components in the treatment of infectious disease. Resistance to medicinal plant extracts have not been described yet and extracts of herbal medicines have been shown to potentiate antibiotic action in resistant pathogens (Garvey et al., 2011; Ohene-Agyei et al., 2014). Therefore, it is likely that as well as antibacterial chemicals, plants may also produce compounds that circumvent effluxmediated resistance. Hence, activity guided fractionation can be used to identify the bio-active phytochemicals in plant extracts with EPI activity against Gram-negative organisms (Garvey et al., 2011).

\section{Tools for Studying Efflux Pump Inhibitors}

The most significant problem in current screening campaigns for EPIs is that in many cases the synergism observed could be attributed to non-specific damage to the bacterial membrane. This would be a strong indicator the compound would have similar activity against mammalian cells and hence would be cytotoxic. This was clearly the case for the EPI PheArg- $\beta$-naphthylamide (PA $\beta N$; Marquez, 2005; Lomovskaya and Zgurskaya, 2011).

Therefore, there need to be a thorough investigation in order to verify true EPI action (Figure 3). Compounds that permeabilise the membrane of Gram-negative organisms will always show synergism with antibiotics. For example, the modulatory effect of $\alpha$-tocopherol in multidrug resistant Gram-negative bacteria such as $P$. aeruginosa and E. coli could most probably be attributed to the effects of $\alpha$-tocopherol on the membrane (Andrade et al., 2014). It is therefore important that potential inhibitors are not only identified on their synergism with antibiotics, but that a subsequent biochemical assays are performed to determine that the compounds are truly acting by inhibiting drug efflux. 


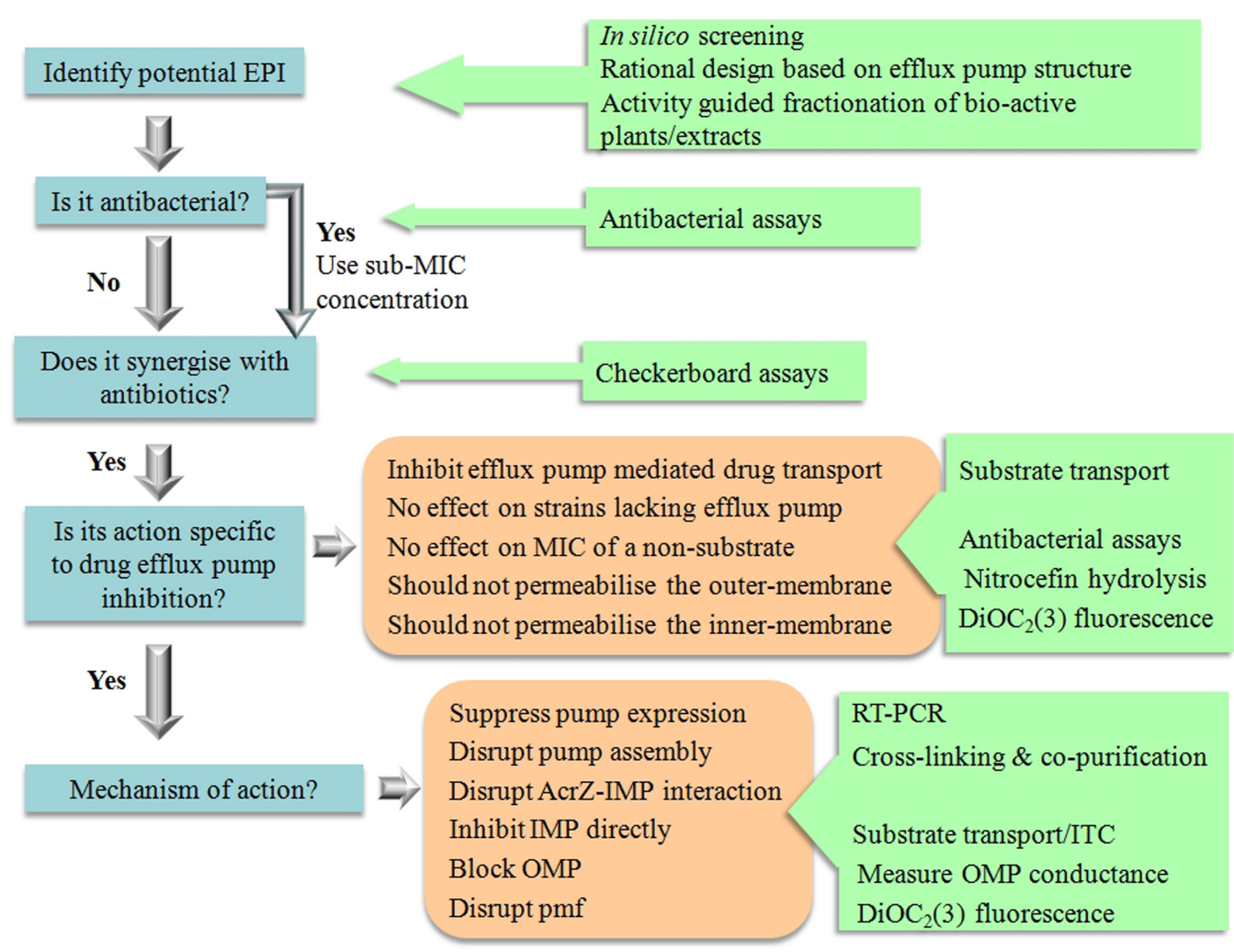

FIGURE 3 | The tools for EPI discovery.

In order to qualify as an EPI a compound must be able to satisfy the following criteria as stipulated by Lomovskaya et al. (2001).

(a) It must potentiate the activity of antibiotics to which a strain has developed resistance as a result of the expression of a drug efflux pump.

(b) It should not have an effect on sensitive strains which lack the drug efflux pump.

(c) It must not reduce the MIC of antibiotics which are not effluxed.

(d) It must increase the level of accumulation and decrease the level of extrusion of compounds which are substrates of the efflux pump.

(e) It must not permeabilise the outer membrane.

(f) It must not affect the proton gradient across the inner membrane.

All the above criteria can be addressed with welldeveloped techniques as outlined below and in Figure 3, which would be amenable to scale-down for high throughput analysis.

\section{Measuring Synergism}

The first thing to do is to determine the MIC of the test compound using standard broth dilution assays (Lomovskaya et al.,
2001; Welch et al., 2010; Ohene-Agyei et al., 2012, 2014). Ideally the compound should not be toxic to bacterial cells or only toxic at high concentrations. This would prevent resistance against the test compound from developing very quickly. The compound would then be used at concentrations below its MIC (usually $4 \times$ lower than the MIC) to test for synergism with antibiotics to which the organism has developed resistance. Synergism is best studied using checkerboard assays. These assays could be performed in a 96-well plate format with the antibiotic serially diluted along the ordinate and the test compound serially diluted along the abscissa (Lomovskaya et al., 2001; Orhan et al., 2005; Ohene-Agyei et al., 2014). The MIC of the antibiotic is determined in the presence of a range of different concentrations of the compound. Antibiotic-EPI interactions are subsequently classified on the basis of fractional inhibitory concentration (FIC). The FIC index is the sum of the FIC of each of the antibiotics, which in turn is defined as the MIC of the antibiotic when used in combination divided by the MIC of the antibiotic when used alone. The combination is considered synergistic when the $\Sigma \mathrm{FIC}$ is $\leq 0.5$, indifferent when the $\Sigma$ FIC is $>0.5$ to $<2$, and antagonistic when the $\Sigma$ FIC is $\geq 2$.

\section{Ensuring the Compound has no Effect on Strains Which Lack the Drug Efflux Pump}

An effective way of testing the effect of a compound on efflux pump mediated resistance is to use a wild-type antimicrobial 
resistant strain and a sensitive strain with a genomic deletion of the IMP. Checkerboard assays can be performed on the wild type strain to determine if MIC drop toward that of sensitive strain. Conversely the compound should not have an effect on the MIC of the sensitive strain.

However, it is important not to use a strain with a TolC deletion. TolC is a multi-functional protein that operates with the majority of MFP-dependent transporters encoded in the genome of E. coli (Zgurskaya et al., 2011). Results from TolC minus cells would therefore be complicated by effects which are not related to active drug efflux (Ohene-Agyei et al., 2014).

\section{Inhibition of Substrate Transport}

The ability of a potential EPI to inhibit substrate transport in a drug efflux pump can be measured by performing substrate accumulation assays or by measuring substrate efflux in the absence/presence of the putative EPI. Many fluorescent compounds are also substrates for drug efflux pumps. If these compounds undergo a change in fluorescence when bound to DNA/membrane lipids they can be used to measure the efflux activity of drug transporters. Many fluorescent compounds fulfill this role and are frequently used to measure drug efflux; examples are Hoechst 33342, berberine, ethidium bromide, TMA-DPH [1-(4-trimethylammoniumphenyl)-6-phenyl-1,3,5-hexatriene ptoluenesulfonate], $N$-phenylnaphthylamine and Nile Red which display enhanced fluorescence intensity when accumulated inside the cell or doxorubicin and rhodamine $6 \mathrm{G}$ for which accumulation inside cells results in quenching of the fluorescence signal (Lee et al., 2001; Lomovskaya et al., 2001; Seeger et al., 2008a,b; Ohene-Agyei et al., 2012, 2014; Cha et al., 2014). In drug accumulation assays the difference in rate of accumulation of the fluorescent compound between cells with and without an active efflux pump are used as an indication of efflux, since efflux will result in lower accumulation of compound. In drug efflux assays, the de-energized cells are preloaded with the fluorescent compound and then energized by the addition of glucose to catalyze drug efflux (observed as a drop in fluorescence). Drug influx assays are more straightforward and much quicker to perform than drug-efflux assays as de-energization and pre-loading can be time consuming. In addition, all the samples must be pre-loaded to the same level of fluorescence to avoid differences in efflux rate as a result of differences in the concentration of drug inside the cell. The main drawback of using fluorescent compounds to measure the effect of an EPI on drug efflux is that the potential EPI could be highly colored or fluorescent itself and thus interfere with the measurement. Recently, Bohnert et al. (2010) developed a method using Nile Red for efflux which are compatible with highly colored or fluorescent compounds.

\section{Testing of Outer Membrane Permeabilization}

The most effective method to measure outer membrane permeabilization is the nitrocefin hydrolysis method. Nitrocefin is a chromogenic $\beta$-lactam which changes from yellow $(\sim 380 \mathrm{~nm})$ to red $(\sim 490 \mathrm{~nm})$ when it is hydrolyzed by the periplasmic $\beta$-lactamase, hence nitrocefin hydrolysis can be followed by measuring the absorbance at $490 \mathrm{~nm}$. If the test compound permeabilises the outer membrane, nitrocefin will diffuse more quickly over the membrane and hence the rate of nitrocefin hydrolysis will increase as a result (Lomovskaya et al., 2001; Ohene-Agyei et al., 2014). It is important to perform these essays in the presence of the ionophore CCCP to de-energize cells and prevent nictrocefin efflux.

\section{Testing of Inner Membrane Permeabilization}

Several methods exist to measure permeabilization of the innermembrane. A DNA stain which does not penetrate the membrane of intact bacterial cells and which will undergo an increase in fluorescence quantum yield when bound to DNA such as propdium iodide or SYTOX Green could be used (Roth et al., 1997; Nakashima et al., 2011). SYTOX Green would be preferred for its sensitivity as it undergoes a $>500$-fold enhancement in fluorescence emission when bound to DNA.

Other methods to measure the intactness of the bacterial inner membrane involve the use or measurement of the pmf in E. coli. Opperman et al. (2014), employed an assay based on the uptake of $\left[\right.$ methyl- $\left.{ }^{3} \mathrm{H}\right] \beta$-D-thiogalactopyranoside $\left(\left[{ }^{3} \mathrm{H}\right] \mathrm{TMG}\right)$ by the LacY permease. The activity of the lactose permease is dependent on the $\mathrm{pmf}$ as it catalysis substrate $/ \mathrm{H}^{+}$symport. Lomovskaya et al. (2001) probed the intracellular pH of E. coli cells by measuring the nuclear magnetic resonance (NMR) of the ${ }^{31} \mathrm{P}$ in the inner-membrane. Although both these two methods are effective they are quite time consuming and require access to specialist equipment. The magnitude of the individual components of the pmf can be measured directly by a simple fluorescence assay utilizing the fluorescent membrane potential probe $3,3^{\prime}$-diethyloxacarbocyanine iodide $\left(\mathrm{DIOC}_{2}(3)\right.$; Venter et al., 2003). Moreover, the $\mathrm{DIOC}_{2}(3)$ assay can easily be adapted to 96-well format for the quick analysis of test compounds on the inner membrane in high-throughput screening.

\section{Use of a Non-Substrate}

Another way of ruling out false positives and establishing that compounds do not act non-specifically is to measure the effect of the test compound on an antibiotic which is not an efflux pump substrate. For example our group used rifampicin, which is not transported by the AcrAB-TolC drug efflux pump from E. coli (Ohene-Agyei et al., 2014). The test compounds should not lower the MIC of rifampicin. Any reduction in the MIC of rifampicin would indicate that the compound does not potentiate antibiotic action by inhibition of efflux, but acts by indirect means such as permeabilization of the membrane.

\section{EPIs Against Gram-Negative Bacteria Identified so Far}

The first EPI to be identified against RND pumps in Gramnegative bacteria was the peptidomimetic PABN, originally referred to as MC-2077110. PA $\beta \mathrm{N}$ was identified in a screen for levofloxacin potentiators against resistant $P$. aeruginosa. Unfortunately, in addition to efflux pump inhibition it also 
TABLE 1 | Efflux pump inhibitors (EPIs) against Gram-negative pathogens.

\begin{tabular}{|c|c|c|c|c|c|}
\hline Compound & Source & $\begin{array}{l}\text { Protein/ } \\
\text { Organism }\end{array}$ & Actions $^{1}$ & Essays performed & Reference \\
\hline \multicolumn{6}{|l|}{ Synthetic Compounds } \\
\hline $\begin{array}{l}\text { Phe-Arg- } \\
\beta \text {-naphthylamide (PA } \beta N \text {; } \\
\text { MC-207,110) }\end{array}$ & Synthetic & $\begin{array}{l}\text { MexAB-OprM, } \\
\text { MexCD-OprJ, } \\
\text { MexEF-OprN } \\
\text { (Pseudomonas } \\
\text { aeruginosa) }\end{array}$ & $\begin{array}{l}\text { Synergise with } \\
\text { fluoroquinolones }\end{array}$ & $\begin{array}{l}\text { Antibacterial } \\
\text { Synergism } \\
\text { Substrate accumulation } \\
\text { Inhibition of efflux } \\
\text { Effect on } \\
\text { outer-membrane }\end{array}$ & $\begin{array}{l}\text { Lomovskaya et al. } \\
\text { (2001) }\end{array}$ \\
\hline $\begin{array}{l}\text { 7-nitro-8-methyl-4-[2' - } \\
\text { (piperidino)ethyl] } \\
\text { aminoquinoline }\end{array}$ & Alkylamino-quinolines & $\begin{array}{l}\text { AcrAB-TolC } \\
\text { (Enterobacter } \\
\text { aerogenes) }\end{array}$ & $\begin{array}{l}\text { Reduced MIC of Cam, Nor, } \\
\text { and Tet } \\
\text { Increased Cam uptake }\end{array}$ & $\begin{array}{l}\text { Antibacterial } \\
\text { Synergism } \\
\text { Substrate accumulation }\end{array}$ & Mallea et al. (2003) \\
\hline $\begin{array}{l}\text { 2,8-dimethyl-4-(2' - } \\
\text { pyrrolidinoethyl)- } \\
\text { oxyquinoline }\end{array}$ & $\begin{array}{l}\text { Alkoxy-quinoline } \\
\text { derivative }\end{array}$ & $\begin{array}{l}\text { E. aerogenes } \\
\text { Klebsiella } \\
\text { pneumonia }\end{array}$ & $\begin{array}{l}\text { Reduced MIC of Nor, Tet, } \\
\text { Cam }\end{array}$ & $\begin{array}{l}\text { Substrate accumulation } \\
\text { Effect on membrane }\end{array}$ & Chevalier et al. (2004) \\
\hline $\begin{array}{l}\text { 1-(1-Naphthylmethyl)- } \\
\text { piperazine } \\
\text { (NMP) }\end{array}$ & Synthetic & $\begin{array}{l}\text { AcrAB, AcrEF } \\
\text { (Escherichia coli) }\end{array}$ & $\begin{array}{l}\text { Reduction in MICs of Lev, } \\
\text { Oxa, Rif, Cam, Clr } \\
\text { Increased accumulation of } \\
\text { ethidium }\end{array}$ & $\begin{array}{l}\text { Antibacterial } \\
\text { Substrate accumulation }\end{array}$ & Kern et al. (2006) \\
\hline $\begin{array}{l}\text { New chloroquinoline } \\
\text { derivatives }\end{array}$ & Fluoroquinolones & $\begin{array}{l}\text { AcrAB-TolC } \\
\text { (E. aerogenes) }\end{array}$ & Reduced MIC of Cam & $\begin{array}{l}\text { Antibacterial } \\
\text { Substrate accumulation }\end{array}$ & Ghisalberti et al. (2006) \\
\hline $\begin{array}{l}\text { 3-amino-6-carboxyl- } \\
\text { indole, } \\
\text { 3-nitro-6-amino-indole }\end{array}$ & $\begin{array}{l}\text { Designed and } \\
\text { synthesized based on } \\
\text { TolC structure }\end{array}$ & $\begin{array}{l}\text { AcrAB-TolC } \\
\text { (E. coli) }\end{array}$ & $\begin{array}{l}\text { Reduced MIC of cam, tet, } \\
\text { ery, and cip }\end{array}$ & $\begin{array}{l}\text { Antibacterial } \\
\text { Synergism }\end{array}$ & Zeng et al. (2010) \\
\hline $\begin{array}{l}\text { 4-(3- } \\
\text { morpholinopropylamino)- } \\
\text { quinazoline }\end{array}$ & $\begin{array}{l}\text { 4-alkylaminoquinazoline } \\
\text { derivatives }\end{array}$ & $\begin{array}{l}\text { AcrAB-TolC } \\
\text { MexAB-OprM } \\
\text { (E. coli } \\
\text { P. aeruginosa) }\end{array}$ & $\begin{array}{l}\text { Reduced MIC of Cam, Nal, } \\
\text { Nor, and Spfx } \\
\text { Increased Cam uptake }\end{array}$ & $\begin{array}{l}\text { Antibacterial } \\
\text { Synergism } \\
\text { Substrate accumulation }\end{array}$ & Mahamoud et al. (2011) \\
\hline MBX2319 & $\begin{array}{l}\text { Synthetic } \\
\text { pyranopyridine }\end{array}$ & AcrB (E. coli) & $\begin{array}{l}\text { Decreased MIC of Cip, Lev, } \\
\text { and } \mathrm{Prl}\end{array}$ & $\begin{array}{l}\text { Docking } \\
\text { Time kill assay } \\
\text { Substrate accumulation } \\
\text { Effect on } \\
\text { outer-membrane } \\
\text { Effect on } \\
\text { inner-membrane }\end{array}$ & $\begin{array}{l}\text { Vargiu et al. (2014), } \\
\text { Opperman et al. (2014) }\end{array}$ \\
\hline $\begin{array}{l}\text { 2-substituted } \\
\text { benzothiazoles }\end{array}$ & Synthetic & $\begin{array}{l}\text { AdeABC } \\
\text { (Acinetobacter } \\
\text { baumannii) }\end{array}$ & Reduced MIC of cip & $\begin{array}{l}\text { Pharmacophore } \\
\text { hypothesis }\end{array}$ & Yilmaz et al. (2014) \\
\hline \multicolumn{6}{|l|}{ Natural Compounds } \\
\hline EA-371 $\alpha$ and EA-371 $\delta$ & $\begin{array}{l}\text { Streptomyces } \\
\text { MF-EA-371-NS1 }\end{array}$ & $\begin{array}{l}\text { MexAB-OprM } \\
\text { (P. aeruginosa) }\end{array}$ & Reduce MIC of Lev & $\begin{array}{l}\text { Synergism } \\
\text { Substrate accumulation }\end{array}$ & Lee et al. (2001) \\
\hline Geraniol & Helichrysum italicum & $\begin{array}{l}\text { E. coli } \\
\text { P. aeruginosa } \\
\text { A. baumanii }\end{array}$ & $\begin{array}{l}\text { Reduced MIC of } \beta \text {-lactams, } \\
\text { quinolones, and Cam }\end{array}$ & $\begin{array}{l}\text { Antibacterial } \\
\text { Synergism }\end{array}$ & Lorenzi et al. (2009) \\
\hline Plumbagin & Plumbago indica & AcrB (E. coli) & $\begin{array}{l}\text { Reduced MIC of Ery, Cam, } \\
\text { TPP, SDS, tet } \\
\text { Inhibition of Nile Red efflux }\end{array}$ & $\begin{array}{l}\text { In silico screening } \\
\text { Antibacterial } \\
\text { Synergism } \\
\text { Non-substrate control } \\
\text { Inhibition of efflux } \\
\text { Effect on } \\
\text { outer-membrane }\end{array}$ & $\begin{array}{l}\text { Ohene-Agyei et al. } \\
\text { (2014) }\end{array}$ \\
\hline $\begin{array}{l}\text { Nordihydroguaretic acid } \\
\text { (NDGA) }\end{array}$ & Creosote bush & $\operatorname{AcrB}(E . c o l i)$ & $\begin{array}{l}\text { Reduced MIC of Ery, Cam, } \\
\text { Nov, Tet, and TPP }\end{array}$ & & \\
\hline Shikonin & $\begin{array}{l}\text { Lithospermum } \\
\text { erythrorhizon }\end{array}$ & $\operatorname{AcrB}(E$. coli) & Reduced MIC of TPP & & \\
\hline $\begin{array}{l}\text { (-)-epigallocatechin } \\
\text { gallate EGCG }\end{array}$ & Green tea & $\begin{array}{l}\text { Campylobacter } \\
\text { spp. }\end{array}$ & $\begin{array}{l}\text { Reduced MIC to Ery and } \\
\text { Cip }\end{array}$ & $\begin{array}{l}\text { Antibacterial } \\
\text { Synergism }\end{array}$ & Kurincic et al. (2012) \\
\hline Curcumin & $\begin{array}{l}\text { Curcuma longa } \\
\text { (Zingiberaceae) }\end{array}$ & $P$. aeruginosa & $\begin{array}{l}\text { Reduced MIC Mem, Carb, } \\
\text { Caz, Gen, and Cip }\end{array}$ & $\begin{array}{l}\text { Antibacterial } \\
\text { Synergism }\end{array}$ & Negi et al. (2014) \\
\hline
\end{tabular}


TABLE 1 | Continued

\begin{tabular}{|c|c|c|c|c|c|}
\hline Compound & Source & $\begin{array}{l}\text { Protein/ } \\
\text { Organism }\end{array}$ & Actions $^{1}$ & Essays performed & Reference \\
\hline $\begin{array}{l}\text { Lanatoside } \mathrm{C} \text { and } \\
\text { diadzein }\end{array}$ & Phytochemical & $\begin{array}{l}\text { AcrB, MexB } \\
\text { (E. coli, } \\
\text { P. aeruginosa) }\end{array}$ & $\begin{array}{l}\text { Reduced MIC of Lev and } \\
\text { Carb } \\
\text { Increased accumulation of } \\
\text { EtBr }\end{array}$ & $\begin{array}{l}\text { High-throughput virtual } \\
\text { screening } \\
\text { Synergism } \\
\text { Substrate accumulation }\end{array}$ & Aparna et al. (2014) \\
\hline 4-hydroxy- $\alpha$-tetralone & Ammannia sp & E. coli & Reduced MIC of Tet & $\begin{array}{l}\text { RT-PCR study } \\
\text { In silico docking }\end{array}$ & Dwivedi et al. (2014) \\
\hline \multicolumn{6}{|c|}{ Non-antibacterial drugs } \\
\hline $\begin{array}{l}\text { Trimethoprim and } \\
\text { Epinephrine }\end{array}$ & $\begin{array}{l}\text { Small heterocyclic or } \\
\text { nitrogen-containing } \\
\text { drugs }\end{array}$ & $\begin{array}{l}\text { S. typhimurium } \\
\text { E. cloacae } \\
\text { S. marcescens } \\
\text { P. aeruginosa } \\
\text { K. pneumoniae } \\
\text { E. coli }\end{array}$ & Reduced MIC of Cip & $\begin{array}{l}\text { Antibacterial } \\
\text { Synergism } \\
\text { Substrate accumulation } \\
\text { Growth kinetics }\end{array}$ & Piddock et al. (2010) \\
\hline $\begin{array}{l}\text { Chlorpromazine, } \\
\text { Amitryptiline, } \\
\text { Trans-chlorprothixene }\end{array}$ & Non-antibiotic drugs & P. aeruginosa & $\begin{array}{l}\text { Reduced MIC of Pen, Cxm, } \\
\text { and Tob }\end{array}$ & $\begin{array}{l}\text { Antibacterial } \\
\text { Synergism }\end{array}$ & Kristiansen et al. (2010) \\
\hline Sertraline & $\begin{array}{l}\text { Selective Serotonin } \\
\text { Re-uptake Inhibitors }\end{array}$ & $\begin{array}{l}\text { AcrAB, AcrEF, MdtEF, } \\
\text { and MexAB }\end{array}$ & Inhibition of Nile Red efflux & $\begin{array}{l}\text { Inhibition of efflux } \\
\text { RT-PCR }\end{array}$ & Bohnert et al. (2011) \\
\hline Artesunate & Anti-malarial drug & AcrAB-TolC (E. coli) & $\begin{array}{l}\text { Reduced MIC of } \beta \text {-lactam } \\
\text { antibiotic } \\
\text { Increased Dau uptake } \\
\text { Reduce mRNA expression }\end{array}$ & $\begin{array}{l}\text { Antibacterial } \\
\text { Synergism } \\
\text { Substrate accumulation } \\
\text { RT-PCR }\end{array}$ & Li et al. (2011) \\
\hline Pimozide & Neuroleptic drug & AcrAB-TolC (E. coli) & $\begin{array}{l}\text { Reduced MICs of Oxa and } \\
\text { EtBr } \\
\text { Inhibition of Nile rRed efflux }\end{array}$ & $\begin{array}{l}\text { Synergism } \\
\text { Substrate efflux }\end{array}$ & Bohnert et al. (2013) \\
\hline
\end{tabular}

${ }^{1}$ Abbreviations used: Cam, Chloramphenicol; Carb , Carbanecillin; Caz, Ceftazidime; Cip , Ciprofloxacin; Clr , Clarithromycin; Cxm , Cefuroxime; Dau , Daunomycin; Ery , Erythromycin; EtBr, Ethidium Bromide; Gen, Gentamicin; Lev , Levofloxacin; Mem , Meropenem; Nal , Nalidixic acid; Nor , Norfloxacin; Oxa, Oxacillin; Pen, Penicillin; Prl, Piperacillin; Rif , Rifampicin; Spfx, Sparfloxacin; Tet, Tetracycline; Tob, Tobramycin; TPP, Triphenylphosphonium.

permeabilized the outer membrane (Lomovskaya et al., 2001). Derivatives of PA $\beta \mathrm{N}$ with reduced toxicity, enhanced stability, and better solubility were developed and advanced to the preclinical stage, however, failed due to toxicity issues (Marquez, 2005; Lomovskaya et al., 2006; Lomovskaya and Zgurskaya, 2011; Bhardwaj and Mohanty, 2012).

The structural basis for the inhibition of the RND transporters has been recently described with the publication of the crystal structures of AcrB from E. coli and MexB from $P$. aeruginosa bound to a pyridopyrimidine derivative D13D900 (Nakashima et al., 2013). The inhibitor binding almost overlapped with the binding of the substrates minocycline and doxorubicin, while part of the inhibitor inserted into a narrow phenylalanine rich region in the deep binding pocket, termed the hydrophobic trap by the authors. The authors suggested that the inhibitor competitively inhibit substrate binding and hinders the functional rotation of the efflux pumps.

As there is only one structure of a RND protein bound to an inhibitor published to date, docking, and molecular simulation studies were used to investigate the putative binding modes of other inhibitors such as PA $\beta \mathrm{N}$ and NMP (Vargiu et al., 2014) while in silico screening also provided information on the binding of putative EPIs (Ohene-Agyei et al., 2014). Both $\mathrm{PA} \beta \mathrm{N}$ an NMP were predicted to interact with the switch loop while D13-D9001and MBX2319 have more interactions with the hydrophobic trap first identified by Nakashima et al. (2013).

Table 1 summarizes the compounds reported to act as EPIs against Gram-negative organisms so far. The term EPI is used loosely here as some of the included compounds were identified based on their synergism with one or more antibiotic while no further analysis was performed to study the mechanism of inhibition or rule out non-specific effects such as membrane permeabilization.

\section{Conclusion}

There are various papers reporting the ability of crude extracts from plants or other organisms to reduce antibiotic resistance that were not dealt with in this review. As can be seen from Table 1, there is also a sizable amount of pure compounds which were able to synergise with antibiotics against drug resistant Gram-negative bacteria. However, the translation of these promising compounds into EPIs for clinical application is still lacking. The most probable reason for the discrepancies in lead compounds and final outcome is the deficiency of follow through from first identification of a compound with synergistic effects to identification of true EPI activity and providing a thorough 
investigation into mechanism of action. With this review we aimed to summarize the current knowledge of how drug efflux can be inhibited.

The tools necessary to identify, test and characterize the mechanism of action of a putative EPI were also provided in order to aid the discovery and development of EPIs with which we would be able to stem the tide of multidrug resistant Gram-negative infections.

\section{References}

Amaral, L., Martins, A., Spengler, G., and Molnar, J. (2014). Efflux pumps of Gramnegative bacteria: what they do, how they do it, with what and how to deal with them. Front. Pharmacol. 4:168. doi: 10.3389/fphar.2013.00168

Andersen, C., Koronakis, E., Hughes, C., and Koronakis, V. (2002). An aspartate ring at the TolC tunnel entrance determines ion selectivity and presents a target for blocking by large cations. Mol. Microbiol. 44, 1131-1139. doi: 10.1046/j.1365-2958.2002.02898.x

Andrade, J. C., Morais-Braga, M. F., Guedes, G. M., Tintino, S. R., Freitas, M. A., Menezes, I. R., et al. (2014). Enhancement of the antibiotic activity of aminoglycosides by alpha-tocopherol and other cholesterol derivates. Biomed. Pharmacother. 68, 1065-1069. doi: 10.1016/j.biopha.2014.10.011

Aparna, V., Dineshkumar, K., Mohanalakshmi, N., Velmurugan, D., and Hopper, W. (2014). Identification of natural compound inhibitors for multidrug efflux pumps of Escherichia coli and Pseudomonas aeruginosa using in silico high-throughput virtual screening and in vitro validation. PLoS ONE 9:e101840. doi: 10.1371/journal.pone. 0101840

Bassetti, M., Merelli, M., Temperoni, C., and Astilean, A. (2013). New antibiotics for bad bugs: where are we? Ann. Clin. Microbiol. Antimicrob. 12, 22. doi: 10.1186/1476-0711-12-22

Baugh, S., Ekanayaka, A. S., Piddock, L. J., and Webber, M. A. (2012). Loss of or inhibition of all multidrug resistance efflux pumps of Salmonella enterica serovar Typhimurium results in impaired ability to form a biofilm. J. Antimicrob. Chemother. 67, 2409-2417. doi: 10.1093/jac/dks228

Baugh, S., Phillips, C. R., Ekanayaka, A. S., Piddock, L. J., and Webber, M. A. (2014). Inhibition of multidrug efflux as a strategy to prevent biofilm formation. J. Antimicrob. Chemother. 69, 673-681. doi: 10.1093/jac/dkt420

Bhardwaj, A. K., and Mohanty, P. (2012). Bacterial efflux pumps involved in multidrug resistance and their inhibitors: rejuvinating the antimicrobial chemotherapy. Recent Pat Antiinfect Drug Discov. 7, 73-89. doi: 10.2174/157489112799829710

Blair, J. M., Smith, H. E., Ricci, V., Lawler, A. J., Thompson, L. J., and Piddock, L. J. (2014). Expression of homologous RND efflux pump genes is dependent upon AcrB expression: implications for efflux and virulence inhibitor design. J. Antimicrob. Chemother. 70, 424-431. doi: 10.1093/jac/dku380

Bohnert, J. A., Karamian, B., and Nikaido, H. (2010). Optimized Nile Red efflux assay of AcrAB-TolC multidrug efflux system shows competition between substrates. Antimicrob. Agents Chemother. 54, 3770-3775. doi: 10.1128/aac. 00620-10

Bohnert, J. A., Schuster, S., and Kern, W. V. (2013). Pimozide Inhibits the AcrAB-TolC Efflux Pump in Escherichia coli. Open Microbiol. J. 7, 83-86. doi: $10.2174 / 1874285801307010083$

Bohnert, J. A., Schuster, S., Seeger, M. A., Fahnrich, E., Pos, K. M., and Kern, W. V. (2008). Site-directed mutagenesis reveals putative substrate binding residues in the Escherichia coli RND efflux pump AcrB. J. Bacteriol. 190, 8225-8229. doi: 10.1128/jb.00912-08

Bohnert, J. A., Szymaniak-Vits, M., Schuster, S., and Kern, W. V. (2011). Efflux inhibition by selective serotonin reuptake inhibitors in Escherichia coli. J. Antimicrob. Chemother. 66, 2057-2060. doi: 10.1093/jac/dkr258

Bumann, D., and Valdivia, R. H. (2007). Identification of host-induced pathogen genes by differential fluorescence induction reporter systems. Nat. Protoc. 2, 770-777. doi: 10.1038/nprot.2007.78

Bush, K., Courvalin, P., Dantas, G., Davies, J., Eisenstein, B., Huovinen, P., et al. (2011). Tackling antibiotic resistance. Nat. Rev. Microbiol. 9, 894-896. doi: $10.1038 /$ nrmicro2693

\section{Acknowledgments}

Work in HV's laboratory is funded by the University of South Australia, the Sansom Institute for Health Research and the Australian Research Council (Grant LE150100203 for screening of EPIs to $\mathrm{HV}$ ). RM is the recipient of an Australian post-graduate award. HV and SM are co-recipients of a China-Australia Centre for Health Sciences Research Grant.

Butler, M. S., and Cooper, M. A. (2011). Antibiotics in the clinical pipeline in 2011. J. Antibiot. (Tokyo) 64, 413-425. doi: 10.1038/ja.2011.44

Cha, H. J., Muller, R. T., and Pos, K. M. (2014). Switch-loop flexibility affects transport of large drugs by the promiscuous AcrB multidrug efflux transporter. Antimicrob. Agents Chemother. 58, 4767-4772. doi: 10.1128/aac. 02733-13

Chevalier, J., Bredin, J., Mahamoud, A., Mallea, M., Barbe, J., and Pages, J. M. (2004). Inhibitors of antibiotic efflux in resistant Enterobacter aerogenes and Klebsiella pneumoniae strains. Antimicrob. Agents Chemother. 48, 1043-1046. doi: 10.1128/AAC.48.3.1043-1046.2004

Chuanchuen, R., Karkhoff-Schweizer, R. R., and Schweizer, H. P. (2003). High-level triclosan resistance in Pseudomonas aeruginosa is solely a result of efflux. Am. J. Infect. Control 31, 124-127. doi: 10.1067/mic.2003.11

Delmar, J. A., Su, C. C., and Yu, E. W. (2014). Bacterial multidrug efflux transporters. Annu. Rev. Biophys. 43, 93-117. doi: 10.1146/annurev-biophys-051013022855

Du, D., Venter, H., Pos, K. M., and Luisi, B. F. (2013). "The machinery and mechanism of multidrug efflux in gram-negative bacteria," in Microbial Efflux Pumps: Current Research, Chap. 3, eds E. W. Yu, Q. Zhang, and M. H. Brown (Ames, IA: Caister Academic Press), 35-48.

Du, D., Wang, Z., James, N. R., Voss, J. E., Klimont, E., Ohene-Agyei, T., et al. (2014). Structure of the AcrAB-TolC multidrug efflux pump. Nature 509, 512-515. doi: 10.1038/nature13205

Dwivedi, G. R., Upadhyay, H. C., Yadav, D. K., Singh, V., Srivastava, S. K., Khan, F., et al. (2014). 4-Hydroxy-alpha-tetralone and its derivative as drug resistance reversal agents in multi drug resistant Escherichia coli. Chem. Biol. Drug Des. 83, 482-492. doi: 10.1111/cbdd.12263

Eicher, T., Brandstatter, L., and Pos, K. M. (2009). Structural and functional aspects of the multidrug efflux pump AcrB. Biol. Chem. 390, 693-699. doi: 10.1515/bc.2009.090

Eicher, T., Cha, H. J., Seeger, M. A., Brandstatter, L., El-Delik, J., Bohnert, J. A., et al. (2012). Transport of drugs by the multidrug transporter AcrB involves an access and a deep binding pocket that are separated by a switch-loop. Proc. Natl. Acad. Sci. U.S.A. 109, 5687-5692. doi: 10.1073/pnas.1114944109

Garvey, M. I., Rahman, M. M., Gibbons, S., and Piddock, L. J. (2011). Medicinal plant extracts with efflux inhibitory activity against Gram-negative bacteria. Int. J. Antimicrob. Agents 37, 145-151. doi: 10.1016/j.ijantimicag.2010. 10.027

Ghisalberti, D., Mahamoud, A., Chevalier, J., Baitiche, M., Martino, M., Pages, J. M., et al. (2006). Chloroquinolines block antibiotic efflux pumps in antibioticresistant Enterobacter aerogenes isolates. Int. J. Antimicrob. Agents 27, 565-569. doi: 10.1016/j.ijantimicag.2006.03.010

Hay, T., Fraud, S., Lau, C. H., Gilmour, C., and Poole, K. (2013). Antibiotic inducibility of the mexXY multidrug efflux operon of Pseudomonas aeruginosa: involvement of the MexZ anti-repressor ArmZ. PLoS ONE 8:e56858. doi: 10.1371/journal.pone.0056858

Hirakata, Y., Kondo, A., Hoshino, K., Yano, H., Arai, K., Hirotani, A., et al. (2009). Efflux pump inhibitors reduce the invasiveness of Pseudomonas aeruginosa. Int. J. Antimicrob. Agents 34, 343-346. doi: 10.1016/j.ijantimicag.2009.06.007

Hirakata, Y., Srikumar, R., Poole, K., Gotoh, N., Suematsu, T., Kohno, S., et al. (2002). Multidrug efflux systems play an important role in the invasiveness of Pseudomonas aeruginosa. J. Exp. Med. 196, 109-118. doi: 10.1084/jem.20020005

Hobbs, E. C., Yin, X., Paul, B. J., Astarita, J. L., and Storz, G. (2012). Conserved small protein associates with the multidrug efflux pump AcrB and differentially affects antibiotic resistance. Proc. Natl. Acad. Sci. U.S.A. 109, 16696-16701. doi: $10.1073 /$ pnas. 1210093109 
Ikonomidis, A., Tsakris, A., Kanellopoulou, M., Maniatis, A. N., and Pournaras, S. (2008). Effect of the proton motive force inhibitor carbonyl cyanide-mchlorophenylhydrazone (CCCP) on Pseudomonas aeruginosa biofilm development. Lett. Appl. Microbiol. 47, 298-302. doi: 10.1111/j.1472-765X.2008.02430.x

Kern, W. V., Steinke, P., Schumacher, A., Schuster, S., von Baum, H., and Bohnert, J. A. (2006). Effect of 1-(1-naphthylmethyl)-piperazine, a novel putative efflux pump inhibitor, on antimicrobial drug susceptibility in clinical isolates of Escherichia coli. J. Antimicrob. Chemother. 57, 339-343. doi: 10.1093/jac/dki445

Krishnamoorthy, G., Tikhonova, E. B., and Zgurskaya, H. I. (2008). Fitting periplasmic membrane fusion proteins to inner membrane transporters: mutations that enable Escherichia coli AcrA to function with Pseudomonas aeruginosa MexB. J. Bacteriol. 190, 691-698 doi: 10.1128/JB.01276-07

Kristiansen, J. E., Thomsen, V. F., Martins, A., Viveiros, M., and Amaral, L. (2010). Non-antibiotics reverse resistance of bacteria to antibiotics. In Vivo 24, 751-754.

Kurincic, M., Klancnik, A., and Smole Mozina, S. (2012). Effects of efflux pump inhibitors on erythromycin, ciprofloxacin, and tetracycline resistance in Campylobacter spp. isolates. Microb Drug Resist. 18, 492-501. doi: $10.1089 / \mathrm{mdr} .2012 .0017$

Lau, C. H., Krahn, T., Gilmour, C., Mullen, E., and Poole, K. (2014). AmgRSmediated envelope stress-inducible expression of the mexXY multidrug efflux operon of Pseudomonas aeruginosa. Microbiologyopen 4, 121-135. doi: $10.1002 / \mathrm{mbo} 3.226$

Lee, E. H., and Shafer, W. M. (1999). The farAB-encoded efflux pump mediates resistance of gonococci to long-chained antibacterial fatty acids. Mol. Microbiol. 33, 839-845. doi: 10.1046/j.1365-2958.1999.01530.x

Lee, M. D., Galazzo, J. L., Staley, A. L., Lee, J. C., Warren, M. S., Fuernkranz, H., et al. (2001). Microbial fermentation-derived inhibitors of efflux-pumpmediated drug resistance. Il Farmaco 56, 81-85. doi: 10.1016/S0014827X(01)01002-3

Lennen, R. M., Politz, M. G., Kruziki, M. A., and Pfleger, B. F. (2013). Identification of transport proteins involved in free fatty acid efflux in Escherichia coli. J. Bacteriol. 195, 135-144. doi: 10.1128/jb.01477-12

Li, B., Yao, Q., Pan, X. C., Wang, N., Zhang, R., Li, J., et al. (2011). Artesunate enhances the antibacterial effect of $\{$ beta\}-lactam antibiotics against Escherichia coli by increasing antibiotic accumulation via inhibition of the multidrug efflux pump system AcrAB-TolC. J. Antimicrob. Chemother. 66, 769-777. doi: 10.1093/jac/dkr017

Lin, J., Cagliero, C., Guo, B., Barton, Y. W., Maurel, M. C., Payot, S., et al. (2005). Bile salts modulate expression of the CmeABC multidrug efflux pump in Campylobacter jejuni. J. Bacteriol. 187, 7417-7424. doi: 10.1128/jb.187.21.74177424.2005

Lomovskaya, O., and Bostian, K. A. (2006). Practical applications and feasibility of efflux pump inhibitors in the clinic-a vision for applied use. Biochem. Pharmacol. 71, 910-918. doi: 10.1016/j.bcp.2005.12.008

Lomovskaya, O., Warren, M. S., Lee, A., Galazzo, J., Fronko, R., Lee, M., et al. (2001). Identification and characterization of inhibitors of multidrug resistance efflux pumps in Pseudomonas aeruginosa: novel agents for combination therapy. Antimicrob. Agents Chemother. 45, 105-116. doi: 10.1128/AAC.45.1.105116.2001

Lomovskaya, O., and Zgurskaya, H. I. (2011). Efflux Pumps from Gram-negative Bacteria: From Structure and Function to Inhibition. Norfolk, VA: Caister Academic press.

Lomovskaya, O., Zgurskaya, H. I., Totrov, M., and Waitkins, W. J. (2006). Waltzing transporters and 'the dance macabre' between humans and bacteria. Nat. Rev. Drug Discov. 6, 56-65. doi: 10.1038/nrd2200

Lorenzi, V., Muselli, A., Bernardini, A. F., Berti, L., Pages, J. M., Amaral, L., et al. (2009). Geraniol restores antibiotic activities against multidrug-resistant isolates from gram-negative species. Antimicrob. Agents Chemother. 53, 22092211. doi: 10.1128 /aac.00919-08

Mahamoud, A., Chevalier, J., Baitiche, M., Adam, E., and Pages, J. M. (2011). An alkylaminoquinazoline restores antibiotic activity in Gram-negative resistant isolates. Microbiology 157(Pt. 2), 566-571. doi: 10.1099/mic.0.045716-0

Mallea, M., Mahamoud, A., Chevalier, J., Alibert-Franco, S., Brouant, P., Barbe, J., et al. (2003). Alkylaminoquinolines inhibit the bacterial antibiotic efflux pump in multidrug-resistant clinical isolates. Biochem. J. 376(Pt. 3), 801-805. doi: $10.1042 /$ bj20030963

Marquez, B. (2005). Bacterial efflux systems and efflux pumps inhibitors. Biochimie 87, 1137-1147. doi: 10.1016/j.biochi.2005.04.012
Martinez, J. L., Sanchez, M. B., Martinez-Solano, L., Hernandez, A., Garmendia, L., Fajardo, A., et al. (2009). Functional role of bacterial multidrug efflux pumps in microbial natural ecosystems. FEMS Microbiol. Rev. 33, 430-449. doi: 10.1111/j.1574-6976.2008.00157.x

Mima, T., Joshi, S., Gomez-Escalada, M., and Schweizer, H. P. (2007). Identification and characterization of TriABC-OpmH, a triclosan efflux pump of Pseudomonas aeruginosa requiring two membrane fusion proteins. J. Bacteriol. 189, 7600-7609. doi: 10.1128/JB.00850-07

Misra, R., and Bavro, V. N. (2009). Assembly and transport mechanism of tripartite drug efflux systems. Biochim. Biophys. Acta 1794, 817-825. doi: 10.1016/j.bbapap.2009.02.017

Murakami, S. (2008). Multidrug efflux transporter, AcrB-the pumping mechanism. Curr. Opin. Struct. Biol. 18, 459-465. doi: 10.1016/j.sbi.2008.06.007

Murakami, S., Nakashima, R., Yamashita, E., Matsumoto, T., and Yamaguchi, A. (2006). Crystal structures of a multidrug transporter reveal a functionally rotating mechanism. Nature 443, 173-179. doi: 10.1038/nature05076

Nakashima, R., Sakurai, K., Yamasaki, S., Hayashi, K., Nagata, C., Hoshino, K., et al. (2013). Structural basis for the inhibition of bacterial multidrug exporters. Nature 500, 102-106. doi: 10.1038/nature12300

Nakashima, R., Sakurai, K., Yamasaki, S., Nishino, K., and Yamaguchi, A. (2011). Structures of the multidrug exporter AcrB reveal a proximal multisite drugbinding pocket. Nature 480, 565-569. doi: 10.1038/nature10641

Negi, N., Prakash, P., Gupta, M. L., and Mohapatra, T. M. (2014). Possible role of curcumin as an efflux pump inhibitor in multi drug resistant clinical isolates of Pseudomonas aeruginosa. J. Clin. Diagn. Res. 8, Dc04-Dc07. doi: $10.7860 / \mathrm{jcdr} / 2014 / 8329.4965$

Nikaido, H. (2011). Structure and mechanism of RND-type multidrug efflux pumps. Adv. Enzymol. Relat. Areas Mol. Biol. 77, 1-60. doi: 10.1002/9780470920541.ch1

Nikaido, H., and Pages, J. M. (2012). Broad-specificity efflux pumps and their role in multidrug resistance of Gram-negative bacteria. FEMS Microbiol. Rev. 36, 340-363. doi: 10.1111/j.1574-6976.2011.00290.x

Nikaido, H., and Takatsuka, Y. (2009). Mechanisms of RND multidrug efflux pumps. Biochim. Biophys. Acta 1794, 769-781. doi: 10.1016/j.bbapap.2008.10.004

Ohene-Agyei, T., Lea, J. D., and Venter, H. (2012). Mutations in MexB that affect the efflux of antibiotics with cytoplasmic targets. FEMS Microbiol. Lett. 333, 20-27. doi: 10.1111/j.1574-6968.2012.02594.x

Ohene-Agyei, T., Mowla, R., Rahman, T., and Venter, H. (2014). Phytochemicals increase the antibacterial activity of antibiotics by acting on a drug efflux pump. Microbiologyopen 3, 885-896. doi: 10.1002/mbo3.212

Opperman, T. J., Kwasny, S. M., Kim, H. S., Nguyen, S. T., Houseweart, C., D'Souza, S., et al. (2014). Characterization of a novel pyranopyridine inhibitor of the AcrAB efflux pump of Escherichia coli. Antimicrob. Agents Chemother. 58, 722-733. doi: 10.1128/aac.01866-13

Orhan, G., Bayram, A., Zer, Y., and Balci, I. (2005). Synergy tests by E test and checkerboard methods of antimicrobial combinations against Brucella melitensis. J. Clin. Microbiol. 43, 140-143. doi: 10.1128/jcm.43.1.140-143.2005

Phillips, J. L., and Gnanakaran, S. (2015). A data-driven approach to modeling the tripartite structure of multidrug resistance efflux pumps. Proteins $83,46-65$. doi: $10.1002 /$ prot.24632

Piddock, L. J. (2006a). Clinically relevant chromosomally encoded multidrug resistance efflux pumps in bacteria. Clin. Microbiol. Rev. 19, 382-402. doi: $10.1128 / \mathrm{cmr} .19 .2 .382-402.2006$

Piddock, L. J. (2006b). Multidrug-resistance efflux pumps? Not just for resistance. Nat. Rev. Microbiol. 4, 629-636. doi: 10.1038/nrmicro1464

Piddock, L. J. (2014). Understanding the basis of antibiotic resistance: a platform for drug discovery. Microbiology 160, 2366-2373. doi: 10.1099/mic.0.082412-0

Piddock, L. J., Garvey, M. I., Rahman, M. M., and Gibbons, S. (2010). Natural and synthetic compounds such as trimethoprim behave as inhibitors of efflux in Gram-negative bacteria. J. Antimicrob. Chemother. 65, 1215-1223. doi: $10.1093 / \mathrm{jac} / \mathrm{dkq} 079$

Poole, K. (2004). Efflux-mediated multiresistance in Gram-negative bacteria. Clin. Microbiol. Infect. 10, 12-26. doi: 10.1111/j.1469-0691.2004.00763.x

Poole, K. (2005). Efflux-mediated antimicrobial resistance. J. Antimicrob. Chemother. 56, 20-51. doi: 10.1093/jac/dki171

Poole, K. (2011). Pseudomonas aeruginosa: resistance to the max. Front. Microbiol. 2:65. doi: $10.3389 /$ fmicb. 2011.00065 
Pos, K. M. (2009). Drug transport mechanism of the AcrB efflux pump. Biochim. Biophys. Acta 1794, 782-793. doi: 10.1016/j.bbapap.2008.12.015

Pumbwe, L., Wareham, D., Aduse-Opoku, J., Brazier, J., and Wexler, H. (2007). Genetic analysis of mechanisms of multidrug resistance in a clinical isolate of Bacteroides fragilis. Clin. Microbiol. Infect. 13, 183-189. doi: 10.1111/j.14690691.2006.01620.x

Purssell, A., and Poole, K. (2013). Functional characterization of the NfxB repressor of the mexCD-oprJ multidrug efflux operon of Pseudomonas aeruginosa. Microbiology 159(Pt. 10), 2058-2073. doi: 10.1099/mic.0.069286-0

Ramos, J. L., Duque, E., Gallegos, M.-T., Godoy, P., Ramos-González, M. I., Rojas, A., et al. (2002). Mechanisms of solvent tolerance in gram-negative bacteria. Ann. Rev. Microbiol. 56, 743-768. doi: 10.1146/annurev.micro.56. 012302.161038

Ricci, V., Busby, S. J., and Piddock, L. J. (2012). Regulation of RamA by RamR in Salmonella enterica serovar Typhimurium: isolation of a RamR superrepressor. Antimicrob. Agents Chemother. 56, 6037-6040. doi: 10.1128/aac.01320-12

Ricci, V., Tzakas, P., Buckley, A., and Piddock, L. J. (2006). Ciprofloxacin-resistant Salmonella enterica serovar Typhimurium strains are difficult to select in the absence of AcrB and TolC. Antimicrob. Agents Chemother. 50, 38-42. doi: 10.1128/aac.50.1.38-42.2006

Rice, A., Liu, Y., Michaelis, M. L., Himes, R. H., Georg, G. I., and Audus, K. L. (2005). Chemical modification of paclitaxel (Taxol) reduces P-glycoprotein interactions and increases permeation across the blood-brain barrier in vitro and in situ. J. Med. Chem. 48, 832-838. doi: 10.1021/jm040114b

Rosenberg, E. Y., Bertenthal, D., Nilles, M. L., Bertrand, K. P., and Nikaido, H. (2003). Bile salts and fatty acids induce the expression of Escherichia coli AcrAB multidrug efflux pump through their interaction with Rob regulatory protein. Mol. Microbiol. 48, 1609-1619. doi: 10.1046/j.1365-2958.2003.03531.x

Roth, B. L., Poot, M., Yue, S. T., and Millard, P. J. (1997). Bacterial viability and antibiotic susceptibility testing with SYTOX green nucleic acid stain. Appl. Environ. Microbiol. 63, 2421-2431.

Ruggerone, P., Murakami, S., Pos, K. M., and Vargiu, A. V. (2013a). RND efflux pumps: structural information translated into function and inhibition mechanisms. Curr. Top. Med. Chem 13, 3079-3100. doi: $10.2174 / 15680266113136660220$

Ruggerone, P., Vargiu, A. V., Collu, F., Fischer, N., and Kandt, C. (2013b). Molecular dynamics computer simulations of multidrug RND efflux pumps. Comput. Struct. Biotechnol. J. 5:e201302008. doi: 10.5936/csbj.201302008

Sanchez, P., Moreno, E., and Martinez, J. L. (2005). The biocide triclosan selects Stenotrophomonas maltophilia mutants that overproduce the SmeDEF multidrug efflux pump. Antimicrob. Agents Chemother. 49, 781-782. doi: 10.1128/AAC.49.2.781-782.2005

Seeger, M. A., Diederichs, K., Eicher, T., Brandstatter, L., Schiefner, A., Verrey, F., et al. (2008a). The AcrB efflux pump: conformational cycling and peristalsis lead to multidrug resistance. Curr. Drug Targets 9, 729-749. doi: $10.2174 / 138945008785747789$

Seeger, M. A., von Ballmoos, C., Eicher, T., Brandstatter, L., Verrey, F., Diederichs, K., et al. (2008b). Engineered disulfide bonds support the functional rotation mechanism of multidrug efflux pump AcrB. Nat. Struct. Mol. Biol. 15, 199-205. doi: 10.1038/nsmb.1379

Seeger, M. A., Schiefner, A., Eicher, T., Verrey, F., Diederichs, K., and Pos, K. M. (2006). Structural asymmetry of AcrB trimer suggests a peristaltic pump mechanism. Science 313, 1295-1298. doi: 10.1126/science.1131542

Segura, A., Molina, L., Fillet, S., Krell, T., Bernal, P., Muñoz-Rojas, J., et al. (2012). Solvent tolerance in gram-negative bacteria. Curr. Opin. Biotechnol. 23, 415-421. doi: 10.1016/j.copbio.2011.11.015

Silver, S., and Phung, L. T. (1996). Bacterial heavy metal resistance: new surprises. Ann. Rev. Microbiol. 50, 753-789. doi: 10.1146/annurev.micro.50.1.753

Starr, L. M., Fruci, M., and Poole, K. (2012). Pentachlorophenol induction of the Pseudomonas aeruginosa mexAB-oprM efflux operon: involvement of repressors NalC and MexR and the antirepressor ArmR. PLoS ONE 7:e32684. doi: 10.1371/journal.pone.0032684
Tegos, G., Stermitz, F. R., Lomovskaya, O., and Lewis, K. (2002). Multidrug pump inhibitors uncover remarkable activity of plant antimicrobials. Antimicrob. Agents Chemother. 46, 3133-3141. doi: 10.1128/AAC.46.10.3133-3141.2002

Tikhonova, E. B., Yamada, Y., and Zgurskaya, H. I. (2011). Sequential mechanism of assembly of multidrug efflux pump AcrAB-TolC. Chem. Biol. 18, 454-463. doi: 10.1016/j.chembiol.2011.02.011

Vargiu, A. V., Ruggerone, P., Opperman, T. J., Nguyen, S. T., and Nikaido, H. (2014). Molecular mechanism of MBX2319 inhibition of Escherichia coli AcrB multidrug efflux pump and Comparison with other inhibitors. Antimicrob. Agents Chemother. 58, 6224-6234. doi: 10.1128/aac.03283-14

Venter, H., Shilling, R. A., Velamakanni, S., Balakrishnan, L., and Van Veen, H. W. (2003). An ABC transporter with a secondary-active multidrug translocator domain. Nature 426, 866-870. doi: 10.1038/nature02173

Walmsley, A. R., and Rosen, B. P. (2009). Transport Mechanisms of Resistance to Drugs and Toxic Metals Antimicrobial Drug Resistance. Berlin: Springer, 111-120. doi: 10.1007/978-1-59745-180-2_10

Wehmeier, C., Schuster, S., Fahnrich, E., Kern, W. V., and Bohnert, J. A. (2009). Site-directed mutagenesis reveals amino acid residues in the Escherichia coli RND efflux pump AcrB that confer macrolide resistance. Antimicrob. Agents Chemother. 53, 329-330. doi: 10.1128/aac.00921-08

Welch, A., Awah, C. U., Jing, S., van Veen, H. W., and Venter, H. (2010). Promiscuous partnering and independent activity of MexB, the multidrug transporter protein from Pseudomonas aeruginosa. Biochem. J. 430, 355-364. doi: $10.1042 / \mathrm{BJ} 20091860$

White, D. G., Goldman, J. D., Demple, B., and Levy, S. B. (1997). Role of the acrAB locus in organic solvent tolerance mediated by expression of marA, soxS, or robA in Escherichia coli. J. Bacteriol. 179, 6122-6126.

WHO. (2014). Antimicrobial Resistance: Global Report on Surveillance 2014. Anvailable at: www.who.int/drugresistance/documents/surveillancereport/en/

Wilke, M. S., Heller, M., Creagh, A. L., Haynes, C. A., McIntosh, L. P., Poole, K., et al. (2008). The crystal structure of MexR from Pseudomonas aeruginosa in complex with its antirepressor ArmR. Proc. Natl. Acad. Sci. U.S.A. 105, 14832-14837. doi: 10.1073/pnas.0805489105

Wong, K., Ma, J., Rothnie, A., Biggin, P. C., and Kerr, I. D. (2014). Towards understanding promiscuity in multidrug efflux pumps. Trends Biochem. Sci. 39, 8-16. doi: 10.1016/j.tibs.2013.11.002

Yilmaz, S., Altinkanat-Gelmez, G., Bolelli, K., Guneser-Merdan, D., OverHasdemir, M. U., Yildiz, I., et al. (2014). Pharmacophore generation of 2-substituted benzothiazoles as AdeABC efflux pump inhibitors in A. baumannii. SAR QSAR Environ. Res. 25, 551-563. doi: 10.1080/1062936x.2014. 919357

Zeng, B., Wang, H., Zou, L., Zhang, A., Yang, X., and Guan, Z. (2010). Evaluation and target validation of indole derivatives as inhibitors of the AcrAB-TolC efflux pump. Biosci. Biotechnol. Biochem. 74, 2237-2241. doi: 10.1271/bbb. 100433

Zhang, Q., Lambert, G., Liao, D., Kim, H., Robin, K., Tung, C. K., et al. (2011). Acceleration of emergence of bacterial antibiotic resistance in connected microenvironments. Science 333, 1764-1767. doi: 10.1126/science.1208747

Zgurskaya, H. I., Krishnamoorthy, G., Ntreh, A., and Lu, S. (2011). Mechanism and function of the outer membrane channel tolc in multidrug resistance and physiology of enterobacteria. Front. Microbiol. 2:189. doi: 10.3389/fmicb.2011.00189

Conflict of Interest Statement: The authors declare that the research was conducted in the absence of any commercial or financial relationships that could be construed as a potential conflict of interest.

Copyright $\odot 2015$ Venter, Mowla, Ohene-Agyei and Ma. This is an open-access article distributed under the terms of the Creative Commons Attribution License (CC BY). The use, distribution or reproduction in other forums is permitted, provided the original author(s) or licensor are credited and that the original publication in this journal is cited, in accordance with accepted academic practice. No use, distribution or reproduction is permitted which does not comply with these terms. 